\title{
IMPLEMENTASI ETIKA BISNIS ISLAM PADA BISNIS SE MANIS DI SITIBONDO
}

\author{
Makhshushi Zakiyah \\ makhshushizakiyah1983@gmail.com \\ Fakultas Syari'ah dan Ekonomi Islam Universitas Ibrahimy Situbondo
}

\begin{abstract}
ABSTRACK
Sejak awal abad ke 20 perkembangan bisnis semakin pesat. Dari waktu ke waktu pertumbuhan bisnis bagaikan jamur setelah musim hujan, ada bisnis yang semakin hari semakin berkembangdan bertahan sukses hingga saat ini, namun tidak jarang ada bisnis yang hanya bisa hidup dan bertahan dalam waktu yang singkat. Persaingan bisnis yang begitu pesat terkadang membuat para pelaku bisnis lupa akan nilai-nilai agama Islam. Se Manis adalah jenis bisnis di era modern yang bergerak dibidang kuliner yang menjual aneka minuman yang berbahan dasar kopi dan lain sebagainya. Se Manis hadir dengan desein best view sesuai dengan kondisi perkembangan zaman modern, sejak maret 2021 hadir pertama kali di desa sumberejo kecamatan banyuputih situbondo, hingga saat ini Agustus 2021 Se Manis telah hadir di kecamatan Bungatan dan Asembagus Se Manis adalah jenis bisnis di era modern yang bergerak dibidang kuliner yang menjual aneka minuman yang berbahan dasar kopi dan lain sebagainya. Se Manis hadir dengan desein best view sesuai dengan kondisi perkembangan zaman modern, sejak maret 2021 hadir pertama kali di desa sumberejo kecamatan banyuputih situbondo, hingga saat ini Agustus 2021 Se Manis telah hadir di kecamatan Bungatan dan Asembagus
\end{abstract}

Keyword: Etika Bisnis Islam, Bisnis Se Manis

\section{PENDAHULUAN}

Islam merespon aktivitas ekonomi dan bisnis secara positif, sehingga semakin banyak manusia yang terlibat dalam aktivitas ekonomi dan bisnis, maka Islam memberikan respon positif terhadap keterlibatan manusia dalam ekonomo dan bisnis, sepanjang tujuan dari proses bisnis sesuai dengan ajaran Islam. Islam tidak memisahkan antara ketaatan dan 
keterlitan manusia dalam berbisnis. Ketaatan seorang pembisnis kepada Allah tidak berimplikasi pada penurunan produktivitas bisnis seseorang, namun sebaliknya justru ketaatan kepada Allah membawa seorang bisnismen menjadi lebih produktif. Oleh karena itu, bisnis juga sebagai media bagi seseorang untuk mendekatkan diri kepada Allad SWT.

Sebagi khalifah fi al-ardhi, manusia merupakan makhluk zoon politicon yang tidak dapat hidup sendiri, manusia membutuhkan orang lain untuk berkomunikasi dan bertransaksi untuk memenuhi kebutuhan hidupnya. Untuk memenuhi kebutuhan seharihari maka manusia akan memerlukan aktivitas ekonomi atau bisnis. Dalam terminology Islam berbisnis termasuk salah satu yang sangat dianjurkan sebagai sarana untuk memenuhi kebutuhan. Bahkan Rasulullah SAW termasuk pelopor bisnis dalam Islam, salahsatu yang dianjurkan oleh Rasullullah SAW adalah aktivitas berbisnis atau berdagang, Rasullah SAW telah menyatakan bahwa sembilan dari sepuluh pintu rezeki adalah melalui berdagang.

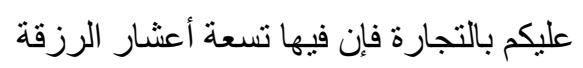

hendaklah kalian melakukan perniagaan (berdagang) karena berdagang merupakan Sembilan dari sepuluh pintu rezeki.

Dalam Islam tujuan berbisnis tidak hanya mencari profit (qimah maddiyah atau nilai materi), namun termasuk yang menjadi tujuan berbisnis dalam Islam adalah benefit (keuntungan atau manfaat) non materi yang dapat dirasakan dan dinikmati oleh pembisnis itu sendiri maupun lingkungan masyarakat sekitar, seperti terciptanya suasana persaudaraan, kepedulian sosial dan lain sebagainya. Dalam bisnis Islam selain tujuan qimah maddiyah masih terdapat satu orientasi bisnis yaitu qimah khuluqiyah (nilai-nilai akhlaq yang mulia).

Sejak awal abad ke 20 perkembangan bisnis semakin pesat. Dari waktu ke waktu pertumbuhan bisnis bagaikan jamur setelah musim hujan, ada bisnis yang semakin hari semakin berkembangdan bertahan sukses hingga saat ini, namun tidak jarang ada bisnis yang hanya bisa hidup dan bertahan dalam waktu yang singkat. Persaingan bisnis yang begitu pesat terkadang membuat para pelaku bisnis lupa akan nilai-nilai agama Islam. Yang menjadi tujuan utama adalah profit semata sehingga seringkali abai dalam prinsip-prinsip yang telah diajarkan oleh Rasulullah SAW. 
Jiwa bisnis yang Islami akan menjadi penentu bagi setiap pembisnis untuk mendapatkan nilai tertinggi dalam aktivitas bisnis sehari-hari. Dianatara nilai Islami adalah nilai keadilan yang berimplikasi pada keadilan sosial dan keadilan ekonomi. Nialai keadilan akan membebaskan masyarakat dari eksploitas individu lain, karena Islam melarang dengan tegas seorang muslim mendzalimi atau merugikan orang lain. Islam juga menganjurkan nilai-nilai spiritualitas dalam berbisnis, bahkan Islam juga ikut andil dalam meluruskan praktik-praktik bisnis yang menyimpang dari ajaran Islam seperti kecurangan, kebohongan, penipuan, propaganda dan lainnya.

Perkembangan bisnis yang begitu pesat seringkali menimbulkan pertikaian dan pertengkaran sengit dikalangan para pembisnis sampai mengabaikan aspek ta'awun (tolong-menolong). Dampak yang kemudian muncul adalah budaya bersaing tidak sehat. Persaingan tidak sehat dalam bisnis akan berdampak kepada para konsumen baik secara langsung ataupun tidak langsung. Secara langsung dampak tersebut berupa terbatasnya persediaan yang tersedia dipasar dan juga akan berdampak terhadap harga kompetitif.

Se Manis adalah jenis bisnis di era modern yang bergerak dibidang kuliner yang menjual aneka minuman yang berbahan dasar kopi dan lain sebagainya. Se Manis hadir dengan desein best view sesuai dengan kondisi perkembangan zaman modern, sejak maret 2021 hadir pertama kali di desa sumberejo kecamatan banyuputih situbondo, hingga saat ini Agustus 2021 Se Manis telah hadir di kecamatan Bungatan dan Asembagus. Bagi kalangan remaja Se Manis seringkali menjadi menu pengantar bincangan dalam setiap perkumpulan dan acara reonian, begitu juga dikalnagan masyarakat luas, Se Manis senantiasa dijadikan teman baik dalam obrolan santai maupun obrolan serius. Terdapat berbagai alasan masyarakat untuk memilih Se Manis sebagai menu dalam setiap obrolan, diantaranya pernyataan bapak Amir

"saya suka Se Manis karena dalam takaran yang dijual menggunakan timbangan yang akurat, sehingga antara rasa dan harga menjadi balance, disamping itu dalam melayani konsumen para crew Se Manis selalu bersikap ramah serta jujur dalam takaran minumannya (wawancara, Amir, 05 Agustus 2021).

Melihat penomena tersebut peneliti akan membahas tentang Implementasi Etika Bisnis Islam pada bisnis Se Manis di Situbondo. Adapun menjadi fokus dalam penelitian 
ini adalah bagaimana etika bisnis Islam yang dilakukan pada bisnis se manis dalam menarik minat konsumen. Sedangkan yang menjadi tujuannya adalah mempresentasikan etika bisnis Islam pada bisnis se Manis dalam menarik minat konsumen.

\section{KAJIAN TEORI}

\section{Bisnis}

Secara harfiah kata bisnis diambil dari bahasa inggris bussines dari kata dasar sibuk baik dalam konteks individu, masyarakat atau kelompok. Pada dasarnya bisnis adalah aktivitas yang dilakukan oleh suatu organisasi atau perorangan dalam hal menjual barang atau jasa kepada konsumen atau kepada pembisnis lainnya dengan tujuan untuk mendapatkan laba. Dalam pandangan kapitalis, bisnis merupakan suatu usaha atau aktivitas yang dilakukan oleh person atau komunitas tertententu untuk mencari keuntungang yang sebesar-besarnya. Dari definisi tersebut, terdapat beberapa ciri-ciri bisnis diantaranya: didalam aktivitas bisnis terdapan beberapa unsur terdapat funsi operasi, pemasaran, menghasilkan barang dan jasa, memperoleh laba atau tidak, serta menghadapi risiko dan ketidak pastian (Muhammad Husni Mubarok, 2010).

Secara etimologi, bisnis adalah seseorang atau sekelompok orang sibuk melakukan pekerjaan yang dapat menghasilkan keuntungan (Budi Untung, 2012). Sedangkan secara terminologi bisnis adalah sebuah aktifitas yang mengarah pada peningkatan nilai melalui proses perdagangan, atau pengolahan barang. Dalam arti luas bisnis merupakan istilah umum yang menggambarkan semua aktifitas dan institusi yang memproduksi barang dan jasa dalam kehidupan sehari-hari. Bisnis merupakan suatu organisasi yang menyediakan barang dan jasa yang bertujuan untuk mendapatkan keuntungan.

\section{Bisnis dalam pandangan Syari'ah}

Islam adalah agama yang syumuliah didalamnya mencakup ajaran-ajaran kehidupan baik kehidupan dunia maupun akhirat. Secara etimologi Islam berasal dari Bahasa Arab yang terambil dari kata salima yang berarti selamat, damai, tunduk, pasrah, dan berserah diri (Adiwarman A Karim, 2017). Sedangkan secara terminologi, Islam adalah agama yang didasarkan pada wahyu Allah yang disampaikan kepada Nabi Muhammad SAW dalam bentuk ayat-ayat Al- Qur'an yang menjadi pedoman bagi seluruh umat manusia. Islam adalah agama yang sempurna yang memuat berbagai persoalan kehidupan yang termasuk 
kehidupan manusia, baik diungkapkan secara global maupun rinci. Secara substansi ajaran Islam yang diturunkan Allah SWT kepada Rasullah SAW terbagi menjadi tiga bagian yakni aqidah, syari'ah dan akhlaq.

Islam merupakan agama yang universal serta konprehensip. Dikatakan universal karena Islam hadir sebagai pedoman dan petunjuk bagi seluruh umat. Dikatakan konferenship sebab Islam mengandung ajaran yang lengkap dan sempurna. Islam mengatur segala aspek kehidupan manusia, baik di bidang ibadah, sosial, politik, ekonomi, hukum, dan lain sebagainya.

\section{Ruang Lingkup Bisnis Syari’ah}

Ada empat prinsip (aksioma) dalam ilmu ikonomi Islam yang mesti diterapkan dalam bisnis syari'ah, yaitu: Tauhid (Unity/kesatuan), Keseimbangan atau kesejajaran (Equilibrium), Kehendak Bebas (Free Will), dan Tanggung Jawab (Responsibility).

Tauhid mengantarkan manusia pada pengakuan akan keesaan Allah selaku Tuhan semesta alam. Dalam kandungannya meyakini bahwa segala sesuatu yang ada di alam ini bersumber dan berakhir kepada-Nya. Dialah pemilik mutlak dan absolut atas semua yang diciptakannya. Oleh sebab itu segala aktifitas khususnya dalam muamalah dan bisnis manusia hendaklah mengikuti aturan-aturan yang ada jangan sampai menyalahi batasanbatasan yang telah diberikan.

Keseimbangan atau kesejajaran (Equilibrium) merupakan konsep yang menunjukkan adanya keadilan sosial. Oleh karena itu Islam melarang adanya tindakan kecurangan dalam aktivitas bisnis

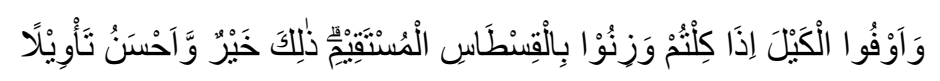

"Dan sempurnakanlah takaran apabila kamu menakar, dan timbanglah dengan neraca yang benar. Itulah yang lebih utama (bagimu) dan lebih baik akibatnya"(Q.S. al-Isra':35)

Dalam beraktivitas di dunia kerja dan bisnis, Islam mengharuskan untuk berbuat adil,tak terkecuali pada pihak yang tidak disukai.

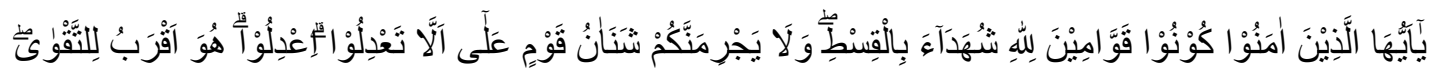

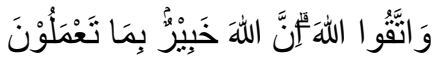


"Hai orang-orang beriman,hendaklah kamu jadi orang-orang yang selalu menegakkan (kebenaran) karena Allah SWT,menjadi saksi dengan adil. Dan janganlah sekali-sekali kebencianmu terhadap suatu kaum mendorong kaти untuk berlaku tidak adil.Berlaku adillah karena adil lebih dekat dengan takwa" (Q.S Almaidah, 8).

kehendak bebas (Free Will) yakni manusia mempunyai suatu potensi dalam menentukan pilihan-pilihan yang beragam, karena kebebasan manusia tidak dibatasi. Tetapi dalam kehendak bebas yang diberikan Allah kepada manusia haruslah sejalan dengan prinsip dasar diciptakannya manusia yaitu sebagai khalifah di bumi. Sehingga kehendak bebas itu harus sejalan dengan kemaslahatan kepentingan individu telebih lagi pada kepentingan umat.

Tanggung Jawab (Responsibility) terkait erat dengan tanggung jawab manusia atas segala aktifitas yang dilakukan kepada Tuhan dan juga tanggung jawab kepada manusia sebagai masyarakat. Karena manusia hidup tidak sendiri dia tidak lepas dari hukum yang dibuat oleh manusia itu sendiri sebagai komunitas sosial. Tanggung jawab kepada Tuhan tentunya diakhirat, tapi tanggung jawab kepada manusia didapat didunia berupa hukumhukum formal maupun hukum non formal seperti sangsi moral dan lain sebagainya.

Menurut Beekun dalam ekonomi Islam terdapat lima aksioma. Sebagai yang kelima adalah Ihsan (benovelence). Dalam konteks ekonomi Islam Ihsan adalah dorongan atau kemauan seseorang untuk selalu berbuat baik dalam bisnis serta dapat meletakkan bisnis pada tujuan kebaikan.

\section{Ciri Khas Bisnis Syari'ah}

Pada hakikatnya bisnis syariah termasuk bagian dari aturan dan syari'at Allah. Dalam praktik bisnis syari'ah terdapat banyak kemiripan bahkan tidak jauh beda dengan bisnis pada umumnya, dimana memproduksi barang dan jasa dengan tujuan untuk memenuhi kebutuhan masyarakat atau konsumen. Akan tetapi dalam bisnis syari'ah terdapat beberapa aspek dasar yang menjadi pembeda dari bisnis pada umumnya. Oleh karena itu selain mengunakan aspek bisnis pada umumnya, dalam bisnis syari'ah selalu menjalankan aturan dan syari'at Allah SWT dalam sebagai dasar dari setiap aktivitas bisnis 
sehingga aspek syari'ah inilah yang membedakan dengan bisnis pada umumnya. Ada pun beberapa cirri bisnis syari' ah antara lain:

Pertama, Bisnis syari'ah Selalu berdasarkan pada aspek nilai Ruhiyah. Nilai ruhiyah merupakan kesadaran pada diri manusia terhadap eksistensi manusia sebagai makhluk Allah SWT yang menyandang perintah untuk selalu kontak atau tunduk serta beribadah kepada Allah SWT.

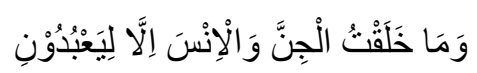

Aku tidak menciptakan jin dan manusia melainkan agar mereka beribadah kepadaKu.(Q.S. Az-zariyat, 56)

Kedua, Pelaku bisnis harus memahami aspek halal dan haram. Pelaku bisnis syariah dituntut mengetahui benar fakta-fakta (tahqiqul manath) terhadap bisnis yang legal syar' $i$ (bisnis boleh dan yang dilarang) serta memahami dasar-dasar nash yang dijadikan hukumnya (tahqiqul hukmi).

Ketiga, Legal Syar'i, kesesuaian antara teori syari'ah dan praktek bisnis yang dijalankan, kesesuai antara pemahaman yang telah digaris bawahi oleh syari'ah dengan apa yang diterapkan oleh pembisnis. Keempat, Orientasi pada keberuntungan dunia dan akhirat (fallah Orientid). Islam tidak melarang pelaku bisnis untuk mencari laba atau keuntungan, namun yang menjadi dasar tidak hanya laba didunia semeata atau keuntungan materi (qimah madiyah).

\section{Etika Bisnis Islam}

Menelusuri asal usul etika tak lepas dari asli kata ethos dalam bahasa yunani yang berarti kebiasaan (custom) atau karakter. Dalam kata lain seperti dalam pemanaan dan kamus webster yang berari karakter istimewa, sentimen Tabiaat moral, atau keyakinan yang membimbing seseorang, kelompok atau institusi.dalam makna yang lebih tegas,yaitu kutipan dalam mendevinisikan etika secara termenologis bahwa etika merupakan study sistematis tentang tabiat konsep nilai dan prinsip prinsip umum yang membenarkan untuk mengaplikasikan atas apa saja. Etika bagi seseorang terwujud dalam nilai kesadaran moral(moral consiusness)yang memuat keyakinan benar dan tidak (Drs. Faisal badroen, MBA dkk , 2006). Pengertian etika berasal dari bahasa Yunani "Ethos" yang berarti kebiasaan atau adat istiadat. Sehingga dapat diartikan bahwa etika berkaitan dengan tata 
cara hidup yang lebih baik, aturan-aturan hidup, nilai-nilai dan segala kebiasaan yang pada umumnya diwariskan dan dilakukan dari satu orang kepada orang lain atau dari satu generasi ke generasi yang lain (Agus Arijanto, 2012).

Etika berasal dari bahasa Yunani kuno "ethos" yang berarti adat kebiasaan yang merupakan hasil dari filsafat. Etika merupakan norma manusia yang harus berjalan, bersikap sesuai nilai atau norma yang ada. Perbedaan akhlaq dan etika ialah bahwa berarti etika merupakan cabang dari filsafat yang bertitik tolak dari akal fikiran, sedangkan akhlaq adalah suatu ilmu pengetahuan yang mengajarkan mana yang baik dan mana yang buruk, berdasarkan ajaran Allah SWT dan Rasulullah SAW (Buchari Alma dan Doni Juni Priansa, 2014). Etika memiliki dua pengertian. Pertama etika sebagaimana moralitas, berarti sistem nilai terkait bagaimana manusia harus hidup dengan baik dalam sebuah adat kebiasaan yang membentuk perilaku yang mana terulang secara terus menerus dalam jangka waktu lama selayaknya kebiasaan. Kedua, etika ini lebih menekankan pada pendekatan kritis dalam melihat nilai dan norma moral dengan segala permasalahannya yang hidup di tengahtengah masyarakat (Muhammad Djakfar, 2012).

Istilah Etika dalam syariah di samakan dengan "Akhlaq budi pekerti, parangai, tabiat, moral, sopan santun dan sebagainya, sebagaimana yang diuraikan oleh Hamza Ya'kup bahwa kta ahklaq berasal dari kata "akhlak" yang berasal dari bahasa arab, yang di artikan sama dengan budi pekerti, perangai, tingkah laku, atau tabiat. Pengertian ahlaq yaitu ilmu yang menentukan batas baik dan buruk, antara yang terpuji dan tercela, tentang perkataan dan perbuatan manusia bukan untuk langsung mengembangkan ekonomi, tapi ahlaq terlebih dahulu. W. F Schoeel bahkan menyatakan prilaku yang etis itu ialah prilaku yang mengikuti perintah Allah SWT serta menjauhi larangannya.

Etika bisnis Islam adalah norma-norma etika yang berbasiskan Al-Qur'an dan Hadist yang harus dijadikan acuan oleh siapapun dalam aktifitas bisnis. Maka dapat disimpulkan bahwa etika bisnis Islam merupakan suatu landasan dalam menjalankan bisnis yang tidak bertentangan dengan ajaran yang terdapat dalam al-qur'an dan Sunnah untuk membedakan antara salah dan benar (Muhammad Djakfar, 2008).

Pada dasarnya terdapat fungsi khusus yang diemban oleh etika bisnis islam. Pertama, etika bisnis berupaya mencari cara untuk menyelaraskan dan menyerasikan 
berbagai kepentingan dalam dunia bisnis. Kedua, etika bisnis juga mempunyai peran untuk senantiasa dilakukan perubahan kesadaran bagi masyarakat tentang bisnis, terutama bisnis islam. Dan caranya biasanya dengan memberikan suatu pemahaman serta cara pandang baru tentang bisnis dengan menggunakan landasan nilai - nilai moralitas dan spritualitas, yang kemudian terangkum dalam suatu bentuk yang bernama etika bisnis. Ketiga, etika bisnis terutama etika bisnis islam juga bisa berperan memberikan satu solusi terhadap berbagai persoalan bisnis modern ini yang kian jauh dari nilai - nilai etika. Dalam arti bahwa bisnis yang beretika harus benar - benar merujuk pada sumber utamanya yaitu $\mathrm{Al}$ qur'an dan Sunnah (Johan Arifin, 2009).

Dalam melakukan segala aktifitas terutama dalam bentuk kegiatan usaha ada etika yang mengatur. Sehingga dalam kegiatan tersebut dapat menimbulkan keharmonisan dan keselarasan antar sesama. Begitu juga dalam dunia berbisnis tidak lepas dari etika bisnis. Etika bisnis merupakan aturan yang mengatur tentang aktifitas bisnis. Adapun berbisnis secara Islami adalah sebagai berikut:

1. Pembisnis harus jujur (shiddiq)

Tanpa kejujuran semua hubungan termasuk hubungan bisnis tidak akan berjalan lama. Padahal dalam prinsip berbisnis interaksi yang memberikan keuntungan sedikit tetapi berlangsung berkali-kali lebih baik daripada untung banyak tetapi hanya sekali atau dua, tiga kali. Rasulullah telah mencontohkan bagaimana sifat jujur dalam berbisnis, bahkan Rasulullah menempatkan posisi khusus bagi mereka yang berbisnis secara jujur.

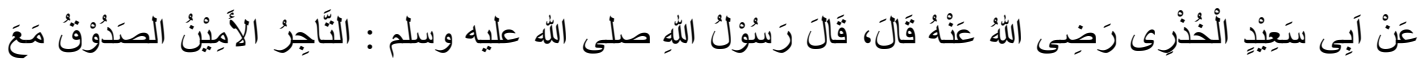

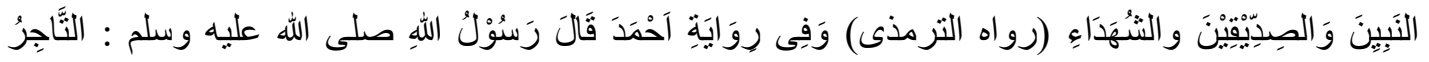

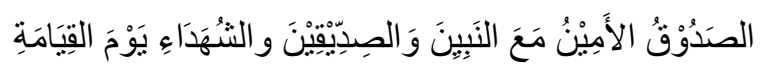


Jujur merupakan motivator yang abadi dalam budi pekerti dan perilaku seorang pembisnis muslim. Karena sebagai salah satu sarana untuk memperbaiki amalannya dan sarana untuk bisa masuk surga.

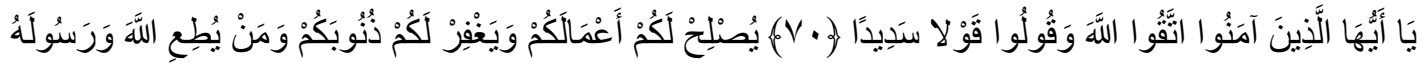

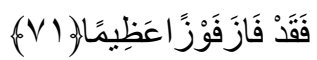

"Wahai orang-orang yang beriman! Bertaqwalah kamu kepada Allah dan ucapkanlah perkataan yang benar. Niscaya Allah akan memperbaiki amal-amalmu dan mengampuni dosa-dosamu. Dan barang siapa menaati Allah dan Rasulnya, maka sungguh dia menang dengan kemenangan yang agung (Q.S. Al-Ahzab ayat 70-71).

2. Amanah

Islam mewajibkan pembisnis untuk mempunyai sikap amanah terhadap diri sendiri dan orang lain apalagi tidak boleh meremehkan hak orang yang memberikan amanah. Karena amanah merupakan tanggung jawab yang besar yang lebih berat dari seluruh yang ada di dunia ini. Dalam berbisnis amanah merupakan tanggung jawab yang besar karena amanah tersebut akan dipertanggungjawabkan tidak hanya sebatas administrasi didunia semata akan tetapi amanah tersebut akan dimintai pertanggung jawaban di hari kiamat kelak.

3. Adil

Islam sangat menganjurkan untuk berbuat adil dalam berbisnis dan melarang berbuat curang. Kecurangan dalam berbisnis pertanda kehancuran bisnis tersebut karena kunci keberhasilan bisnis adalah keadilan. Bersikap adil dalam bertransaksi berdampak baik kepada hasil jualannya karena konsumen akan merasakan kenyamanan dan tidak ada yang dilebihkan serta dirugikan (M.Quraisy Shihab, 2008).

4. Toleransi dan keramah-tamahan

Dalam Islam berbisnis tidak sekedar memperoleh keuntungan materi semata, tetapi juga menjalin hubungan harmonis yang pada gilirannya menguntungkan kedua belah pihak harus mengedepankan toleransi. Ramah merupakan sifat terpuji yang dianjurkan oleh agama Islam untuk siapa saja dan kepada siapa saja. Dengan ramah, maka orang yang suka 
dan dengan ramah banyak pula orang yang senang. Karena ramah merupakan bentuk aplikasi dari kerendahan hati seseorang.

5. Keterbukaan dan kebersamaan

Kesediaan pelaku bisnis untuk menerima pendapat orang lain yang lebih benar serta menghidupkan potensi dan inisiatif yang kreatif dan positif. Tidak hanya dengan keterbukaan, seorang bisnis haruslah menjalin kerjasama dalam membagi beban serta memikul tanggung jawab tanpa ada diskriminasi diantara pelaku bisnis. Standar baik dan buruk menurut ajaran Islam berbeda dengan ukuran-ukuran lainnya. Untuk menilai apakah sesuatu perbuatan itu baik atau buruk, juga harus diperhatikan kriteria (bagaimana cara melakukan perbuatan itu).

\section{Ruang Lingkup Etika Bisnis Syari’ah}

Bisnis syari'ah pada dasarnya etika bisnis syari'ah tidak jauh berbeda dengan etika bisnis pada umumnya, hanya saja terdapat beberapa ruang lingkup etika bisnis syari'ah yang dapat membedakannya dengan etika bisnis pada umumnya. Pertama, Etika bisnis menghimbau pelaku bisnis agar menjalankan bisnisnya dengan baik dan etis. Bisnis yang baik dan etis akan mempengaruhi keberhasilan usaha dalam jangka panjang dan berfungsi menggugah kesadaran moral para pelaku bisnis untuk berbisnis secara baik dan etis demi nilai-nilai luhur tertentu dan demi kepentingan bisnisnya sendiri. Etika bisnis dalam lingkupnya yang pertama ini tidak hanya menyangkut perilaku dan organisasi Perusahaan secara internal, melainkan juga menyangkut secara eksternal.

Kedua, Untuk menyadarkan masyarakat, khususnya konsumen, buruh atau karyawan dan masyarakat luas akan hal dan kepentingan mereka yang tidak boleh dilanggar oleh praktek bisnis siapapun juga. Pada tingkat ini berfungsi menjaga hak dan kewajiban masing - masing, agar tidak terdapat kecurangan yang berfungsi untuk mengambil hak dan kewajiban setiap orang yang bersifat merugikan orang tersebut, disini dituntut untuk mengutamakan keadilan dalam setiap bisnis yang dilakukan oleh para pelaku-pelaku bisnis.

Ketiga, Etika bisnis juga berbicara mengenai sistem ekonomi yang sangat etis atau tidaknya suatu praktek bisnis. Pada tingkatn ini etika bisnis berbicara olygopoly, monopoli, kolusi dan praktek semacamnya yang akan merugikan dan mempengaruhi suatu ekonomi disuatu negara.

Jurnal al-Idārah | 85 


\section{METODE PENELITIAN}

Metode penelitian merupakan komponen yang sangat penting demi keberhasilan suatu penelitian, karena penelitian dapat dikatakan berhasil jika dengan metode atau cara yang sistematis dan teratur, sehingga permasalahan dapat terpecahkan dan tujuan penelitian dapat dirumuskan dengan baik. Oleh karena itu metode penelitian ini dapat dipandang vital peranannya, dalam penulisan karya ilmiah. Dalam buku karya Sugiyono yang membahas tentang penelitian kualitatif dan kuantitatif menjelasakan bahwa metode penelitian kualitatif dapat diartikan sebagai metode penelitian yang berlandaskan pada filsafat Postpositivisme, digunakan untuk meneliti objek alamiah di mana peneliti adalah instrumen kunci (Sugiyono, 2012).

Penelitian ini menggunakan penelitian kualitatif. Permasalahan-permasalahan yang ada dalam penelitian ini bersifat dinamis, holistic, dan fenomonologi. Oleh karena itu, penelitian kualitatif merupakan penelitian yang metode penelitiannya digunakan untuk meneliti objek yang alamiah. Penelitian kualitatif menekankan pada quality atau hal yang terpenting dari sifat suatu barang atau jasa. Adapun sumber data yang digunakan dalam penelitian ini adalah sumber data primer dan skunder. Data primer diperoleh secara langsung melalui teknik observasi, wawancara dan dokumentasi terhadap objek penelitian. Sedangkan sumber data sekunder adalah sumber data yang diperoleh dari buku, atau litaratur yang lainnya.

\section{HASIL DAN PEMBAHSAN}

\section{Bisnis Se Manis}

Bisnis Se Manis adalah bisnis yang bergererak di bidang kuliner terfokus pada penjualan aneka miniman yang terbuat dari bahan dasar kopi, teh dan lain sebagainya. Awal mula berdiri di SPBU desa Sumberejo kecematan Banyuputih Kabupaten Situbondo pada bulan maret 2021 dan sudah memiliki cabang di Kecamatan Bungatan dan Asembagus pada Agustus 2021. Kehadiran bisnis ini mendapat tanggapan positif dari berbagai kalangan, disamping tempat yang strategis alat-alat yang digunakan juga sudah modrn.

\section{Etika Bisnis Islam Pada Se Manis}

Sebagai muslim, berbisnis tidak hanya mencari keuntungan yang telah digambarkan dalam prinsip kapitalis. Namun, bisnis bagi kalangan muslim adalah sebagai sarana ibadah 
kepada Allah SWT, Dalam menjalankan bisnis, Se Manis selalu mengedepankan nilai-nilai Islami dan diawali nengan niat untuk membangun bisnis menuju jalan akhirat. Yang menjadi tujuan dari bisnis ini diantaranya adalah untuk mencari ridla Allah SWT, serta membantu untuk mebuka lapangan pekerjaan bagi masyarakat setempat. Keberlangsungan bisnis Se Manis menjadi harapan utama bagi owner se manis, oleh karena itu se manis perlu meningkatkan minat konsumen. Untuk meningkatkan minat konsumen bisnis Se Manis selalu mengedepankan nilai-nilai etika bisnis dalam Islam.

\section{Prinsip Tauhid}

Allah sebagai penentu kehidupan manusia dan alam sekitarnya. Se Manis menjadikan prinsip tauhid sebagai landasan awal dalam aktivitas bisnis. Landasan tauhid bertitik tolak pada niat dan tujuan Se Manis adalah untuk berdakwah dijalan Allah SWT melalui pemberdayaan ekonomi ummat serta memberikan mamfa'at kepada seluruh ummat. Oleh karena itu dalam aktifitas bisnis Se Manis selalu dikaitkan dengan nilai-nilai ubudiyah.

Keesaan ini secara khusus menunjukkan dimensi vertical islam yang menghubungkan institusi-institusi social yang terbatas dan tak sempurna dengan zat yang sempurna dan tak terbatas. Hubungan vertical ini merupakan wujud penyerahan diri manusia secara penuh tanpa syarat dihadapan tuhan dengan menjadikan keinginan, ambisi serta perbuatannya tunduk pada titahh-Nya:

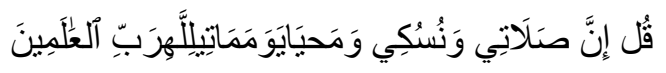

Katakanlah: Sesungguhnya sembahyangku, ibadatku, hidupku dan matiku hanyalah untuk Allah, Tuhan semesta alam"

Dalam hal ini apaun aktifitas yang dilakukan oleh Se Manis semuanya dikembalikan kepada Allah, dalam hal ini Se Manis berusaha semaksimal mungkin sesuai bangunan konsep bisnis namun hasilnya dipasrahkan kepada apa yang telah di anugrahkan Oleh Allah.

\section{Tanggung Jawab}

Akuntabilitas dan tanggung jawab merupakan kesedian pelaku bisnis untuk mempertanggungjawabkan seluruh aktifitas bisnis. Pada prakteknya bisnis Se Manis meyakini bahwa seluruh aktivitas bisnis yang dijalankan selalu dalam pantauan Allah SWT. 
Oleh karena itu, sebagai tolak ukur dari nilai tanggung jawab adalah Se Manis dengan selalu melakukan pelayanan prima kepada setiap konsumen dan pelanggan. Sebagai khalifah di bumi manusia memiliki kebebasan untuk mengarahkan kehidupannya pada tujuan yang diingankannya. Kebebasan berarti bahwa pembisnis sebagai individu dan kolektif mempunyai kebebasan penuh untuk melakukan aktifitas bisnis, namun kebebasan tersebut bukan berarti kebebasan tanpa batas.

\section{Jujur}

Dalam mengimplementasikan nilai-nilai etika bisnis Islam, Se Manis selalu mengimplementasikan tentang pentingnya kejujuran, karena kejujuran merupakan jalan menuju kesuksesan, hal ini dapat di lihat dari aktifitas Se Manis yang mengedepankan mutu untuk terjaminnya kwalitas minuman yang disajikan. Untuk membangun kerangka Kejujuran salah satunya dapat direalisasikan dalam praktek penggunaan timbangan untuk mengukur takaran minuman yang dibeli oleh pelanggan ataupun konsumen sehingga karyawan Se Manis tidak membedakan antara kepentingan pribadi maupun orang lain. Dengan adanya sikap jujur itu kepercayaan pembeli kepada penjual akan tercipta dengan sendirinya

\section{KESIMPULAN}

Penerapan etika bisnis Islam yang diterapkan oleh Se Manis telah sesuai dengan prinsip-prinsip dasar etika bisnis Islam yaitu: Mengutamakan prinsip uluhiyah atau prinsip tauhid, prinsip tanggung jawab dan kejujuran, dalam aspek takaran dengan mengedepankan mutu dan kualitas terbaik kepada konsumen. Menjual barang yang baik mutunya yakni menjaga mutu dan kualitas barang merupakan suatu yang penting dijaga oleh produsen, dalam hal ini Se Manis menggunakan bahan-bahan yang bermutu. Longgar dan bermurah hati ketika menetapkan harga dan ketika melayani konsumen, serta produsen juga memberi potongan harga kepada konsumen.

\section{DAFTAR PUSTAKA}

Adiwarman A Karim. (2017). Bank Islam: Analisis Fiqih dan Keuangan. Depok: PT Raja Grafindo.

Agus Arijanto. (2012). Etika Bisnis Bagi Pelaku Bisnis. Jakarta: Raja Grafindo. 
Buchari Alma dan Doni Juni Priansa. (2014). Manajemen Bisnis Syari'ah. Bandung: Alfabeta CV.

Budi Untung. (2012). Hukum dan Etika Bisnis. Yogyakarta: Andi.

Drs. Faisal badroen, MBA dkk . (2006). Etika Bisnis Dalam Islam. Jakartar: Pramenadia Group.

Johan Arifin. (2009). Etika Bisnis Islam. Semarang : Walisongo Press.

M.Quraisy Shihab. (2008). Berbisnis Dengan Allah. Tanggerang: Lentera Hati .

Muhammad Djakfar. (2008). Etika Bisnis Islam. Malang: UIN Malang Press.

Muhammad Djakfar. (2012). Etika Bisnis. Jakarta: Penebar Swadaya.

Muhammad Husni Mubarok. (2010). Pengantar Bisnis. Kudus: Nora Media Enterprise.

Sugiyono. (2012). Metode Penelitian Pendidikan. Bandung: Alfabeta. 